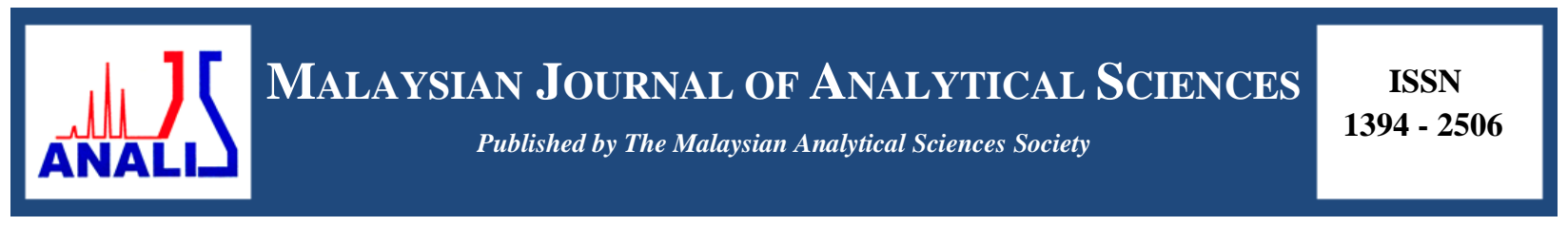

\title{
SYNTHESIS, CHARACTERIZATION AND DNA BINDING ACTIVITY OF A POTENTIAL DNA INTERCALATOR
}

\author{
(Sintesis dan Pengikatan DNA oleh Sebatian Interkalasi DNA Yang Berpotensi) \\ Siti Norain Harun, Yaakob Razak, Haslina Ahmad* \\ Faculty of Science, \\ Universiti Putra Malaysia, 43400 UPM Serdang, Selangor, Malaysia \\ *Corresponding author: haslina_ahmad@upm.edu.my
}

Received: 17 August 2015; Accepted: 23 May 2016

\begin{abstract}
A novel complex, $\left[\mathrm{Ru}(\mathrm{dppz})_{2}(p-\mathrm{MOPIP})\right]^{2+}(\mathrm{dppz}=$ dipyrido-[3,2-a:20,30-c]phenazine, $p$-MOPIP = 2-(4-methoxyphenyl) imidazo[4,5-f][1,10]phenanthroline) has been synthesized and characterized by elemental analysis, ${ }^{1} \mathrm{H}$ Nuclear Magnetic Resonance spectroscopy, mass spectrometry, Fourier Transform Infrared analysis, Ultra Violet visible and fluorescence spectroscopy. Herein, the complex was designed by adding $p$-MOPIP as an intercalating ligand and dppz as the ancillary ligand. The DNA binding properties of the complex with Calf Thymus DNA (CT-DNA) were investigated using spectroscopic methods. The UV-visible absorption band observed at $460 \mathrm{~nm}$ corresponded to the metal-to-ligand charge transfer (MLCT) while bands at 358 and $281 \mathrm{~nm}$ corresponded to intra-ligand (IL) $\pi$ - $\pi^{*}$ transitions of the ligand scaffold in $p$-MOPIP and dppz. The intrinsic binding constant, $\mathrm{K}_{\mathrm{b}}$ for this complex was $1.67 \times 10^{6} \mathrm{M}^{-1}$ and this suggested that this complex, $\left[\mathrm{Ru}(\mathrm{dppz})_{2}(\mathrm{p}-\mathrm{MOPIP})\right]^{2+}$ bound to DNA via the intercalative mode. Interestingly, the interaction of this complex with CT-DNA also had a 'molecular light switch' effect.
\end{abstract}

Keywords: ruthenium, DNA binding, molecular light switch

\begin{abstract}
Abstrak
Satu kompleks baru, $\left[\mathrm{Ru}(\mathrm{dppz})_{2}(p-\mathrm{MOPIP})\right]^{2+}(\mathrm{dppz}=$ dipyrido-[3,2-a:20,30-c]fenazin, $p$-MOPIP = 2-(4-metoksifenil) imidazo[4,5-f][1,10]fenantrolina) telah dihasilkan dan dianalisis dengan menggunakan analisis elemen, spektroskopi resonans magnet nukleus ( ${ }^{1} \mathrm{H}$ NMR), spektrometri jisim, analisis inframerah tranformasi Fourier (FTIR), spektroskopi ultra-lembayung dan pendafluor. Penyediaan kompleks telah dilakukan dengan menambah $p$-MOPIP sebagai ligan interkalasi dan dppz sebagai ligan sisi. Ciri-ciri ikatan DNA bagi kompleks ini dengan Calf Thymus DNA (CT-DNA) telah dianalisis dengan menggunakan kaedah spektroskopik. Jalur pada $460 \mathrm{~nm}$ merujuk kepada caj metal-kepada-ligan (MLCT), manakala jalur pada $358 \mathrm{dan} 281 \mathrm{~nm}$ dikaitkan dengan peralihan $\pi-\pi^{*}$ intra-ligan (IL) bagi ligan $p$-MOPIP dan dppz. Nilai pemalar ikatan, $\mathrm{K}_{\mathrm{b}}$ ialah $1.67 \times 10^{6} \mathrm{M}^{-1}$ dan keputusan eksperimen mencadangkan pengikatan berlaku melalui mod interkalasi. Menariknya, kompleks ini juga menunjukkan kesan 'suis cahaya molekul'.
\end{abstract}

Kata kunci: ruthenium, pengikatan DNA, suis cahaya molekul

\section{Introduction}

Ruthenium, as other transition metals, generally have the electronic configuration where the $4 \mathrm{~d}$ sub-shells are partially filled [1], allowing it to form different sorts of complexes that are suitable for various applications including as anticancer drugs, biosensors, in catalysis and others. Ruthenium complexes have properties that make them active biologically [2]. One of the properties is ligand exchange, where ruthenium(II) and ruthenium(III) 
complexes having similar exchange kinetics to those of platinum(II) complexes [3], thus, are able to display similar biological effects as platinum(II) drugs. Additionally, ruthenium has a wide range of accessible oxidation states [4], for instance, ruthenium(II), ruthenium(III) or ruthenium(IV). The reduction and oxidation (redox) potential of metal complexes can be modified and exploited by varying the ligands to improve the effectiveness of ruthenium based drugs in the pharmaceutical industry [5]. Ruthenium(II) complexes with $\mathrm{d}^{6}$ configuration are predominantly are octahedral and diamagnetic [6]. Recently, researchers have been more focused on the ruthenium(II) polypyridyl complexes due to their photoluminescence which makes them stable and also suitable as DNA probes.

Previously, the development of classical ruthenium drugs was based on the capability of ruthenium to bind with DNA via some of the nitrogen atoms of nucleic bases. The interaction between transition metal complexes and nucleic acids were studied extensively in order to develop drugs that could react and bind to nucleic bases. The most important characteristics of ruthenium(II) complexes are that their intercalating ligand must possess extended and planar aromatic structures which is able to stack and insert between the base pairs of the DNA double helix. The intercalating ligand plays an important role in order to make the interaction with DNA happen.

The modification of polypyridyl ligands would allow fine tuning of the configuration and electronic structures of ruthenium(II) polypyridyl complexes therefore, varying the DNA binding properties of these complexes. Nowadays, the researchers are more interested in the complexes that contain one intercalating ligand and two ancillary ligands due to their stability, strong DNA affinity, photochemical properties and various other applications. Ruthenium complexes with stable, inert, coordinatively saturated and water soluble properties are the most ideally suited and extremely valuable as non-covalent probes of both structural and functional aspects of nucleic acid chemistry [7].

Thus, the objective of this study is to synthesis, characterization and evaluate the DNA binding activity of a potential DNA intercalator based on novel complex, $\left[\mathrm{Ru}(\mathrm{dppz})_{2}(\mathrm{p}-\mathrm{MOPIP})\right]^{2+}$.

\section{Materials}

\section{Materials and Methods}

All the chemicals and solvents in this experiment are at least of analytical grade and used as received from the suppliers unless stated otherwise. The reagents used without purification are as follows: ruthenium(III) chloride hydrate, 4-methoxybenzaldehyde, 1,10-phenanthroline, sodium bromide, sodium hydrogen carbonate, magnesium sulfate, ammonium acetate, $o$-phenylene diamine, lithium chloride $(\mathrm{LiCl})$, potassium hexaflorophosphate $\left(\mathrm{KPF}_{6}\right)$ and tetra- $N$-butylammoniumchloride. The solvents are listed as follows: nitric acid, sulphuric acid, chloroform, methanol, glacial acetic acid, aqueous ammonia, dimethylformamide, toluene, acetonitrile and ethylene glycol.

\section{Instrumentation}

The elemental analysis of the complex was carried out by using Leco CHNS-932 Elemental Analyzer. The nuclear magnetic resonance (NMR) spectra was recorded at room temperature in deuterated acetonitrile $\left(\mathrm{CD}_{3} \mathrm{CN}\right)$ by using JEOL ECX500 FT NMR $500 \mathrm{MHz}$ spectrometer with tetramethylsilane (TMS) as the internal standard for ${ }^{1} \mathrm{H}$. Electrospray Ionization Mass Spectrometry (ESI-MS) of the complex was performed on a triple stage quadrupole Finnigan TSQ7000 mass spectrometer with a diverted inject valve where the spectra recorded were in the scanning range of $50-2200 \mathrm{~m} / \mathrm{z}$ ratio. The Infrared absorption spectra were measured by using Perkin Elmer 100 series FTIR Spectrometer in the range $4000-200 \mathrm{~cm}^{-1}$. UV-Visible spectra were recorded over the range of $200-600 \mathrm{~nm}$ on Shimadzu H.U.V.1650 PC UV-Visible spectrophotometer using quartz cells of $10 \mathrm{~mm}$ path length. Emission spectra were recorded over the range $500-850 \mathrm{~nm}$ using an excitation wavelength of $460 \mathrm{~nm}$ on a Shimadzu RF5301 PC spectrofluorometer at room temperature.

\section{Preparation of the precursor ligand and complex}

The precursor ligand, 1,10-phenanthroline-5,6-dione was prepared according to literature [8] and recrystallized in methanol. The precursor ligand was later used to prepare dipyrido[3,2-a:2',3'-c]phenazine (dppz) [9] and 2-(4methoxylphenyl)imidazo[4,5-f][1,10]phenanthroline ( $p$-MOPIP) [10] by following literature methods. 


\section{Synthesis of $\mathrm{Ru}(\mathrm{dppz})_{2} \mathrm{Cl}_{2}$}

$\mathrm{Ru}(\mathrm{dppz})_{2} \mathrm{Cl}_{2}$ was prepared according to an established method [11]. A mixture of $0.2 \mathrm{~g}$ (1.0 mmol) $\mathrm{RuCl}_{3} .3 \mathrm{H}_{2} \mathrm{O}$, $0.55 \mathrm{~g}(2.0 \mathrm{mmol}) \mathrm{dppz}, 0.22 \mathrm{~g}$ of $\mathrm{LiCl}$, and $30 \mathrm{~mL}$ of DMF was refluxed for 8 hours. The dark solution was stirred in $100 \mathrm{~mL}$ of chilled acetone and then kept in the freezer overnight. The crude product was collected by filtration and washed with water. The dried crude product was a fine dark purple powder. Yield: $0.623 \mathrm{~g}(80.1 \%), \mathrm{MS}, \mathrm{m} / \mathrm{z}$ : $703\left[\mathrm{M}^{+}-2 \mathrm{Cl}\right] ;{ }^{1} \mathrm{H}$ NMR $500 \mathrm{MHz}\left(\mathrm{CD}_{3} \mathrm{CN}, \delta \mathrm{ppm}\right): 9.50(\mathrm{~d}, 4 \mathrm{H}), 9.17(\mathrm{~d}, 4 \mathrm{H}), 8.38(\mathrm{dd}, 4 \mathrm{H}), 8.04(\mathrm{dd}, 4 \mathrm{H})$ and $7.92(\mathrm{~d}, 4 \mathrm{H})$; IR $\left(\mathrm{v}, \mathrm{cm}^{-1}\right): 3057.49\left(\mathrm{sp}^{2} \mathrm{C}-\mathrm{H}\right), 1631.00(\mathrm{C}=\mathrm{N}), 1581.31(\mathrm{C}=\mathrm{C}), 1073.58(\mathrm{C}-\mathrm{N})$ and $327.32(\mathrm{Ru}-\mathrm{Cl})$.

\section{Synthesis of $\left.\left[\mathrm{Ru}(\mathrm{dppz})_{2} p \text {-MOPIP }\right]_{2}\right]^{2+}$}

A mixture of $0.034 \mathrm{~g}(0.10 \mathrm{mmol}) p$-MOPIP, $0.08 \mathrm{~g}(0.10 \mathrm{mmol})$ of $\left[\mathrm{Ru}(\mathrm{dppz})_{2} \mathrm{Cl}_{2}\right]^{2+}$ was dissolved in $10 \mathrm{ml}$ of ethylene glycol and refluxed for 4 hours under nitrogen. Upon cooling, concentrated $\mathrm{KPF}_{6}$ solution was added into the dark solution. Once the precipitation was complete, the solution was filtered by using a grade- 4 crucible followed by washing with water. The crude product was purified by column chromatography by using neutral alumina with a 1:1 ratio of acetonitrile and toluene. The orange-red band was collected and analyzed. The final product was a fine dark orange solid. Yield: $0.08 \mathrm{~g}(62.5 \%$ ); Found: C, 53.2; H, 2.67; N, 13.2 (calculated for $\left.\mathrm{C}_{56} \mathrm{~F}_{12} \mathrm{H}_{34} \mathrm{~N}_{12} \mathrm{OP}_{2} \mathrm{Ru}: \mathrm{C}, 52.4 ; \mathrm{H}, 3.0 ; \mathrm{N}, 13.1\right)$; $\mathrm{MS}, \mathrm{m} / z: 1136.9\left[\mathrm{M}^{+}-\mathrm{PF}_{6}{ }^{-}\right]$and $993.2\left[\mathrm{M}^{+}-2 \mathrm{PF}_{6}{ }^{-}\right], ;{ }^{1} \mathrm{H}$ NMR $\left(\mathrm{CD}_{3} \mathrm{CN}, \delta \mathrm{ppm}\right): 9.65(\mathrm{~d}, 6 \mathrm{H}, J=6.87 \mathrm{~Hz}), 9.05(\mathrm{~d}, 4 \mathrm{H}, J=8.02 \mathrm{~Hz}), 8.43(\mathrm{~m}, 6 \mathrm{H}), 8.23(\mathrm{dd}, 4 \mathrm{H}, J=3.44 \mathrm{~Hz}), 8.15$ $(\mathrm{d}, 2 \mathrm{H}, J=9.16 \mathrm{~Hz}), 7.82(\mathrm{~m}, 4 \mathrm{H}), 7.69(\mathrm{dd}, 2 \mathrm{H}, J=5.73 \mathrm{~Hz}), 7.20(\mathrm{~d}, 2 \mathrm{H}, J=9.16 \mathrm{~Hz})$ and $3.88(\mathrm{~s}, 3 \mathrm{H}) ; \mathrm{IR}\left(v, \mathrm{~cm}^{-1}\right)$ :3386.03 (secondary N-H), $2954.87\left(s p^{3} \mathrm{C}-\mathrm{H}\right), 1458.91(\mathrm{C}=\mathrm{C}), 1354.91(\mathrm{C}=\mathrm{N}), 1022.27(\mathrm{C}-\mathrm{N})$ and $811.44(\mathrm{Ar}$ para-subs.)

\section{UV-Visible titration}

The interaction of ruthenium(II) complex, $\left[\mathrm{Ru}(\mathrm{dppz})_{2}(p-\mathrm{MOPIP})\right]^{2+}$ with CT-DNA was analyzed using UV-Vis spectroscopy. The UV-Vis titration of the complex in a buffer was performed at room temperature using a fixed concentration of the complex with increasing concentration of DNA. The concentration of the $\left[\mathrm{Ru}(\mathrm{dppz})_{2}(p-\right.$ MOPIP) $]^{2+}$ solution was $15 \mu \mathrm{M}$ while the concentration of DNA titrated varied from 0 to $86 \mu \mathrm{M}$. The complexDNA solution was allowed to incubate for 10 minutes before the spectra were recorded. The titration processes were repeated several times until no more changes were observed in the spectra which indicated that the binding saturation was achieved. The changes in the concentration of the ruthenium(II) complex due to dilution at the end of each titration were negligible.

\section{Emission titration}

The intrinsic fluorescence emission spectra of the complex in Tris-buffer was carried out by using a fixed ruthenium(II) concentration to which increments of the DNA stock solution were added. Ruthenium-DNA solution was allowed to incubate for 5 minutes before the emission spectra were recorded. The excitation wavelength was set at $460 \mathrm{~nm}$.

\section{Viscosity measurements}

Viscosity measurements were carried out with an Cannon Flask viscometer, suspended vertically and immersed in a water bath with a constant temperature of $25^{\circ} \mathrm{C}$. The flow time was measured with a digital stopwatch and each sample was tested three times to obtain the average flow time. Data were represented as $\left(\eta / \eta_{0}\right)^{1 / 3}$ versus binding ratio, $1 / \mathrm{R}$ where $\eta$ is the viscosity of DNA in the presence of the complex. Specific viscosity values were calculated by the equation $\eta=\left(t-t_{0}\right) / t_{0}$, where $t$ and $t_{0}$ represent flow time of the DNA solution and the blank buffer, respectively.

\section{Results and Discussion}

The reaction of $\left[\mathrm{Ru}(\mathrm{dppz})_{2} \mathrm{Cl}_{2}\right]$ with $p$-MOPIP in a ratio $1: 1$ treated with potassium fluorophosphate resulted in formation of $\left[\mathrm{Ru}(\mathrm{dppz})_{2} \mathrm{p}-\mathrm{MOPIP}\right]^{2+}$ in $\mathrm{PF}_{6}$ salt (Scheme 1). The purified complex was obtained as an orange-red fine solid with $62.5 \%$ yield. Conversion to chloride salts was done with the treatment of the complex in acetonitrile solution with tetra- $N$-butylammoniumchloride. The complex in $\mathrm{PF}_{6}$ salt was easily soluble in acetonitrile while as a chloride salt, it was soluble in water. 

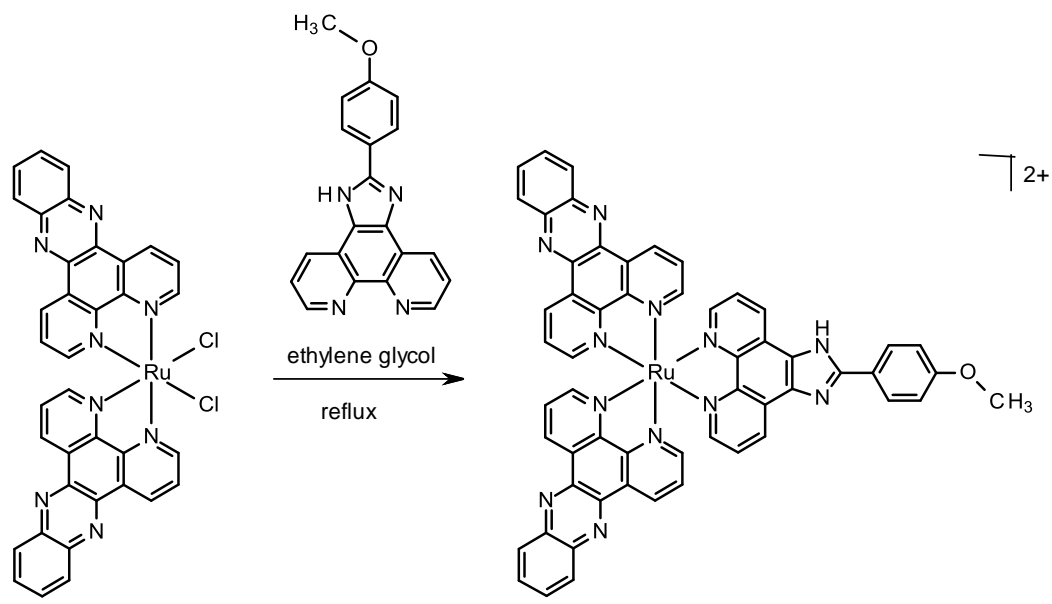

Scheme 1. Preparation of $\left[\mathrm{Ru}(\mathrm{dppz})_{2} p-\mathrm{MOPIP}\right]^{2+}$

Electrospray ionization mass spectrometry (ESI-MS) in acetonitrile showed a peak at $\mathrm{m} / z 1136.9$ for $\left[\mathrm{M}^{+}\right]$while the intense peak at $\mathrm{m} / \mathrm{z} 496.1$ served as the base peak for $\left[\mathrm{M}^{2+}\right]$. The ${ }^{1} \mathrm{H}$ NMR spectrum of $\left[\mathrm{Ru}(\mathrm{dppz})_{2} \mathrm{p}-\mathrm{MOPIP}\right]^{2+}$ (Figure 1) in deuterated acetonitrile were properly defined and integrated. There are nine signals which corresponded to the protons of dppz and $p$-MOPIP ligands in the complex. The resonance at $9.65 \mathrm{ppm}$ corresponded to the proton attached to the carbon adjacent to a coordinated nitrogen atom in the aromatic ring while the proton attached to the neighboring oxygen atom was shielded at $7.20 \mathrm{ppm}$. The proton signal for the methyl group was observed at $3.88 \mathrm{ppm}$ as a singlet peak. Unfortunately, the signal that corresponded to the proton directly attached to nitrogen atom in $p$-MOPIP was not observed in the spectrum, probably due to fast exchange chemistry of the active proton in the imidazole ring or it was obscured by the nitrogen quadrapole broadening property [12]. However, the presence of NH was confirmed by the IR spectrum.

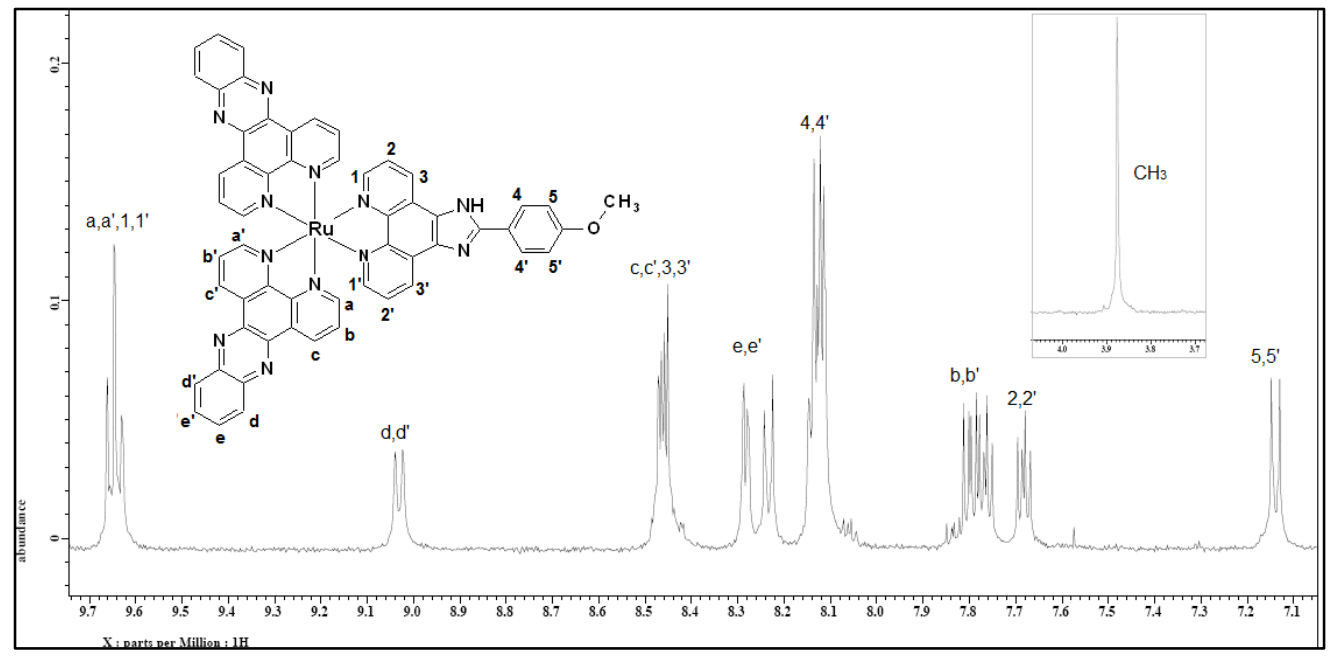

Figure 1. ${ }^{1} \mathrm{H}$ NMR spectrum of $\left[\mathrm{Ru}(\mathrm{dppz})_{2} p-\mathrm{MOPIP}\right]^{2+}$

The IR spectrums of the complex were recorded in the region of $4000-280 \mathrm{~cm}^{-1}$ and the data is summarized in Table 1. A broad and strong peak which gives information on secondary amine group of imidazole $v(\mathrm{~N}-\mathrm{H})$ was 
observed at $3386 \mathrm{~cm}^{-1}$. The carbon-nitrogen bonds absorptions $v(\mathrm{C}=\mathrm{N})$ and $v(\mathrm{C}-\mathrm{N})$ were at 1638 and $1354 \mathrm{~cm}^{-1}$, respectively. The stretching frequency of $v(\mathrm{C}-\mathrm{O})$ at $1022 \mathrm{~cm}^{-1}$ were indicative of the $\mathrm{O}-\mathrm{CH}_{3}$ group. In addition, a strong out of plane $v(\mathrm{C}-\mathrm{H})$ bending frequency appeared at $811 \mathrm{~cm}^{-1}$ indicating that the substitution in the aromatic phenyl referred to the para-position. The accumulated MS, NMR and IR data supported by elemental analysis was consistent with the proposed structure and composition of the complex.

Table 1. IR data of $\left[\mathrm{Ru}(\mathrm{dppz})_{2} p-\mathrm{MOPIP}\right]^{2+}$

\begin{tabular}{ccl}
\hline $\boldsymbol{v}$ & Wave number $\left(\mathbf{c m}^{-\mathbf{1}}\right)$ & Intensity \\
\hline$(\mathrm{N}-\mathrm{H})$ & 3386 & strong, broad \\
$\left(s p^{3} \mathrm{C}-\mathrm{H}\right)$ & 2954 & strong, sharp \\
$(\mathrm{C}=\mathrm{N})$ & 1638 & medium, sharp \\
$(\mathrm{C}=\mathrm{C})$ & 1458 & strong, sharp \\
$(\mathrm{C}-\mathrm{N})$ & 1354 & strong, sharp \\
$(\mathrm{C}-\mathrm{O})$ & 1022 & medium \\
Para subs ring & 811 & medium \\
\hline
\end{tabular}

The UV-Visible absorption spectrum for $\left[\mathrm{Ru}(\mathrm{dppz})_{2} \mathrm{p}-\mathrm{MOPIP}\right]^{2+}$ was recorded in acetonitrile, with a concentration of $10 \mu \mathrm{M}$ at room temperature. Through comparison to related molecules $[8,9]$, the bands centered at around 281 $\mathrm{nm}\left(\varepsilon=66600 \mathrm{M}^{-1} \mathrm{~cm}^{-1}\right)$ and $358 \mathrm{~nm}\left(\varepsilon=17400 \mathrm{M}^{-1} \mathrm{~cm}^{-1}\right)$ were assigned to intra-ligand $\pi \rightarrow \pi^{*}$ transitions in the scaffold. The lowest energy band at $460 \mathrm{~nm}\left(\varepsilon=10200 \mathrm{M}^{-1} \mathrm{~cm}^{-1}\right)$ was attributed to the metal-to-ligand charge transfer (MLCT) transition of the $\mathrm{Ru}\left(\mathrm{d}_{\pi}\right) \rightarrow$ ligand. The luminescence spectra of the complex upon MLCT excitation was performed at room temperature and the excitation wavelength was set at $460 \mathrm{~nm}$. Figure 2 displays the emission spectra of complex in acetone (blue) and water (red) at room temperature to show the effect of the protic solvent on the complex. The complex displayed high luminescence in acetonitrile but almost no emission in water probably due to the presence of the dppz ligands in the complex. In an aqueous environment, the free electron on the nitrogen of the phenazine ring can form hydrogen bonds with water molecules [13,14]. As a result, the excited-state luminescence was quenched $[15,16]$. This property is advantageous in DNA-binding studies using an aqueous buffer, where the complex binds to DNA, and the dppz ligands were protected from water, thus intense luminescence could be observed. This phenomenon has been termed as the 'molecular light switch' effect [17].

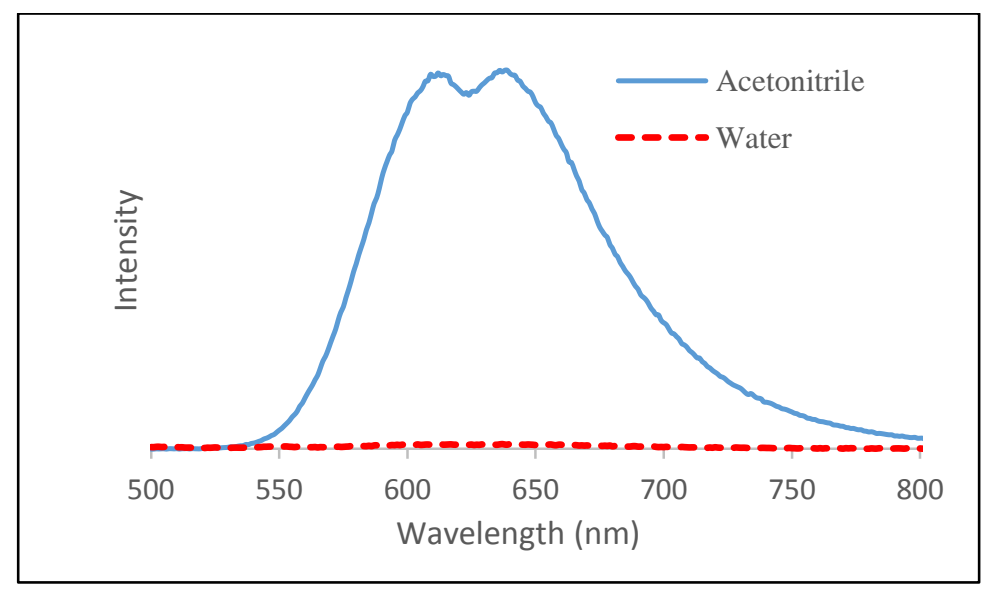

Figure 2. Luminescence spectra of $\left[\mathrm{Ru}(\mathrm{dppz})_{2} p-\mathrm{MOPIP}\right]^{2+}$ in acetonitrile and water 


\section{DNA-binding studies}

The interaction of the ruthenium(II) complex, $\left[\mathrm{Ru}(\mathrm{dppz})_{2}(p-\mathrm{MOPIP})\right]^{2+}$ with CT-DNA was analyzed using UV-Vis spectroscopy. The UV-Vis titration of the complex in a buffer was performed at room temperature using a fixed concentration of the complex with increasing concentration of DNA.

The concentration of the $\left[\mathrm{Ru}(\mathrm{dppz})_{2}(p-\mathrm{MOPIP})\right]^{2+}$ solution was at $15 \mu \mathrm{M}$ while the concentration of DNA varried from 0 to $86 \mu \mathrm{M}$. The complex-DNA solution was allowed to incubate for 10 minutes before the spectra were recorded in order to allow the interaction between DNA and the complex. The titration processes were repeated several times until no more changes were observed in the spectra indicating that the binding saturation was achieved. The changes in the ruthenium(II) complex concentration due to dilution at the end of each titration were too small and thus were negligible [18]. The absorption spectrum of complex with increasing concentration of CTDNA is shown in Figure 3.

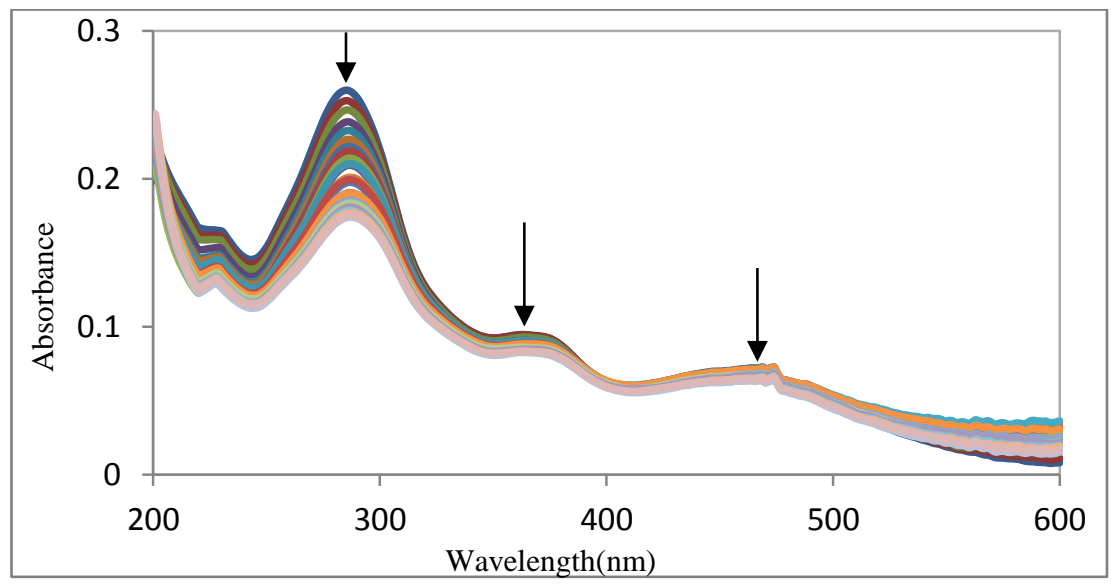

Figure 3. Absorption spectra of ruthenium(II) complex in Tris-HCl buffer upon addition of CT-DNA. [Complex] = $15 \mu \mathrm{M},[\mathrm{DNA}]=0-86 \mu \mathrm{M}$

The arrows showed the absorbance changing upon the increase in DNA concentration. Normally, the hypochromic and bathochromic effects are seen during the binding process which is due to the perturbation of the metal centred MLCT band and the ligand centred $\pi-\pi^{*}$ band of the complex [19]. For this case, although there was no obvious red shift, hypochromicities was observed. The hypochromicities in the absorption bands for $\left[\mathrm{Ru}(\mathrm{dppz})_{2}(p \text {-MOPIP })\right]^{2+}$ complex by the addition of CT-DNA in aqueous buffer was $29 \%$. This hypochromism effect has been attributed to the presence of synergic non-covalent interactions: electrostatic, groove or intercalation binding along the outside of DNA helix, and often the extent of hypochromism was parallel to the intercalative binding strength [20].

There were three well resolved bands at $284 \mathrm{~nm}, 363 \mathrm{~nm}$ and $474 \mathrm{~nm}$. The absorption bands decreased with higher concentration of CT-DNA which fit a characteristic feature of CT-DNA binding interaction. The ultraviolet bands at $284 \mathrm{~nm}$ and $363 \mathrm{~nm}$ correlated to the intra-ligand $\pi-\pi^{*}$ transition [19]. The lowest energy bands at $474 \mathrm{~nm}$ was assigned to the MLCT transitions pf $\mathrm{Ru}\left(\mathrm{d}_{\pi}\right) \rightarrow$ ligand according to the other related ruthenium (II) complexes [21].

In order to quantitatively illustrate the DNA binding strength of the complex, the intrinsic binding constant, $\mathrm{K}_{\mathrm{b}}$ of complex with CT-DNA was determined by monitoring the changes of absorbance at $284 \mathrm{~nm}$ while increasing the concentration of DNA according to the following equation 1 [22]:

$$
[D N A] /\left(\varepsilon_{\mathrm{a}}-\varepsilon_{\mathrm{f}}\right)=[\mathrm{DNA}] /\left(\varepsilon_{\mathrm{b}}-\varepsilon_{\mathrm{f}}\right)+1 / \mathrm{K}_{\mathrm{b}}\left(\varepsilon_{\mathrm{b}}-\varepsilon_{\mathrm{f}}\right)
$$


where [DNA] is the concentration of CT-DNA in base pairs, the apparent absorption coefficient, $\varepsilon_{\mathrm{a}}, \varepsilon_{\mathrm{f}}$ and $\varepsilon_{\mathrm{b}}$ correspond to $\mathrm{A}_{\text {observed }} /[\mathrm{Ru}]$, the extinction coefficient for the free ruthenium complex and the extinction coefficient for the free ruthenium complex in the fully bound form, respectively .

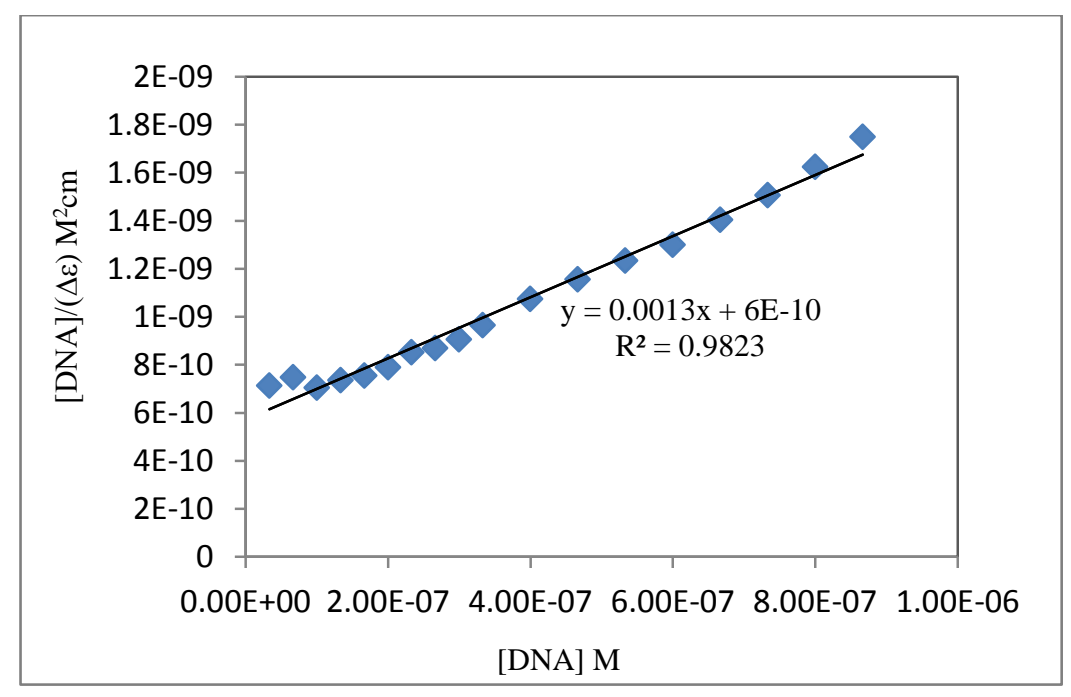

Figure 4. [DNA]/( $\Delta \varepsilon)$ vs $[\mathrm{DNA}]$ for the titration of DNA with the ruthenium(II)complex

$\mathrm{K}_{\mathrm{b}}$ was determined by the ratio of slope to the intercept and the value obtained was $1.67 \times 10^{6} \mathrm{M}^{-1}$. By comparing with other similar ruthenium(II) complexes that contained $p$-MOPIP as ligand, this value was greater compared to $\left[\mathrm{Ru}(\mathrm{bpy})_{2}(p \text {-MOPIP] }]^{2+}\right.$ and $\left[\mathrm{Ru}(\text { phen })_{2}(p \text {-MOPIP })\right]^{2+}$ where the value of $\mathrm{K}_{\mathrm{b}}$ were $5.0 \times 10^{5} \mathrm{M}^{-1}$ and $0.20 \times 10^{5} \mathrm{M}^{-1}$ $[10,13]$, respectively. This signified that $\left[\mathrm{Ru}(\mathrm{dppz})_{2}(p \text {-MOPIP })\right]^{2+}$ bound more tightly to DNA compared to those complexes. In this case, the ancillary ligand dppz might have played an important influence suggesting that the high DNA binding affinity was relative to the dimension of $\pi$-conjugated aromatic area of ancillary ligands. This was mainly induced by the extended-aromatic structure of the ancillary ligand which was dppz that increased the action between the complexes and DNA. The dppz itself might also react with DNA consequently giving a higher value of binding constant as mentioned before.

The $K_{b}$ value was consistent with previous report by Sun et al. [23] on a closely related compound consisting of two dppz ligands in one system, $\left[\operatorname{Ru}(\mathrm{dppz})_{2}\left(\mathrm{~L}^{1}\right)\right]^{2+},\left(\mathrm{L}^{1}=5,5^{\prime}\right.$-di(1-(trimethylammonio)methyl)-2,2'-dipyridyl cation) showed the effect of the intercalating ligand in DNA binding, with $\mathrm{K}_{\mathrm{b}}$ values at $0.58 \times 10^{6} \mathrm{M}^{-1}$. The distinct structure of $p$-MOPIP which comprised of an extended aromatic area assisted $\left[\mathrm{Ru}(\mathrm{dppz})_{2}(p-\mathrm{MOPIP})\right]^{2}$ to bind strongly to DNA through intercalation compared to $\left[\mathrm{Ru}(\mathrm{dppz})_{2}\left(\mathrm{~L}^{1}\right)\right]^{2+}$ where $\mathrm{L}^{1}$ contained longer alkyl groups in the ligand. The binding affinity of $\left[\mathrm{Ru}(\mathrm{dppz})_{2}(p \text {-MOPIP })\right]^{2+}$ was improved by bis-intercalation due to presence of more than one intercalating ligand in one system, namely $p$-MOPIP and two sites of dppz $[8,14]$.

The intrinsic fluorescence emission spectra of complex in Tris buffer was carried out by using a fixed ruthenium(II) concentration to which increments of the DNA stock solution were added. Ruthenium-DNA solution was allowed to incubate for 10 minutes before the emission spectra were recorded. The excitation wavelength was set at $460 \mathrm{~nm}$.

In the emission spectra (Figure 5), the arrow showed the emission intensity changes upon increasing the DNA concentration. The concentrations of the ruthenium(II) complex and CT-DNA were $30 \mu \mathrm{M}$ and $0-200 \mu \mathrm{M}$, respectively. The interaction of the complex with DNA shows increased emission intensity in buffer solution. However, the emission changes were not so pronounced even after excess addition of DNA because of solvent quenching and enhancement of emission intensity when bound intercalatively to DNA. This implied that the 
ruthenium(II) complex could strongly interact with DNA and be protected by DNA efficiently. In other words, the hydrophobic environment inside the DNA helix reduced the accessibility of solvent water molecules to the complex and the complex mobility was restricted at the binding site [24], leading to a decrease of the vibrational modes of relaxation. Increase in emission was an indication of intercalation between CT-DNA and the complex.

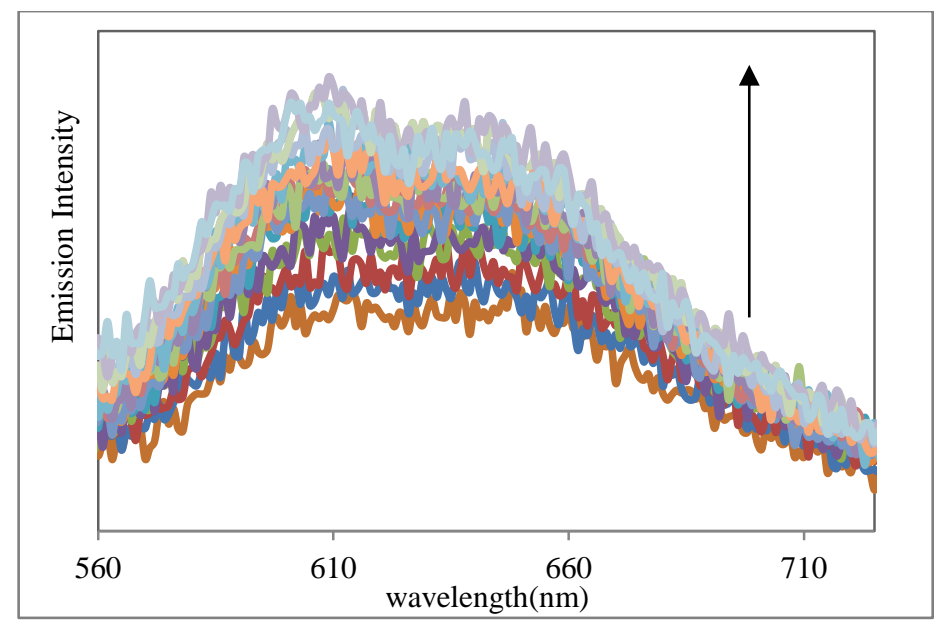

Figure 5. The emission spectra of the ruthenium(II) complex in buffer in the presence of increasing amounts of CT-DNA, $[\mathrm{Ru}]=30 \mu \mathrm{M},[\mathrm{DNA}]=0-200 \mu \mathrm{M}$

This result also revealed the selective nature of $\left[\mathrm{Ru}(\mathrm{dppz})_{2}(p \text {-MOPIP })\right]^{2+}$ as a molecular switch, responding sensitively to the suitable changes in the structure of the helix, a phenomenon called the 'molecular light switch' effect, due to presence of the dppz ligands.

In order to elucidate the binding mode of $\left[\mathrm{Ru}(\mathrm{dppz})_{2}(p \text {-MOPIP })\right]^{2+}$, viscosity measurements were carried out by keeping a constant concentration of CT-DNA and varying the concentration of the complex. Viscosity measurements provided reliable evidence to study the mode of interaction. Electrostatic or groove binding generally had no significant consequence on the viscosity of DNA, whereas classical intercalation affects the lengthening of DNA helix as base pairs are separated to accommodate foreign molecules, therefore, increasing the viscosity of DNA [25]. As shown in Figure 6, with continuing addition of $\left[\mathrm{Ru}(\mathrm{dppz})_{2}(p-\mathrm{MOPIP})\right]^{2+}$ to CT-DNA solution, the viscosity of CT-DNA increased. This result validated the hypothesis that $\left[\mathrm{Ru}(\mathrm{dppz})_{2}(p-\mathrm{MOPIP})\right]^{2+}$ bound to DNA via intercalation. This result was in agreement with other previous reports on ruthenium(II) polypyridyl complexes $[10,26]$.

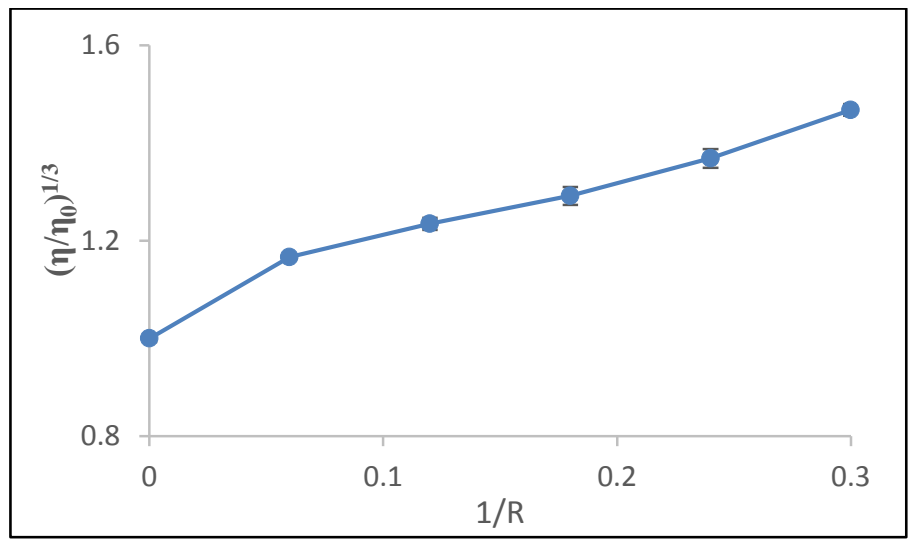

Figure 6. Effect of increasing concentration of $\left[\mathrm{Ru}(\mathrm{dppz})_{2}(p-\mathrm{MOPIP})\right]^{2+}$ on the viscosity of CT-DNA 


\section{Conclusion}

In this study, a novel complex $\left[\mathrm{Ru}(\mathrm{dppz})_{2}(p-\mathrm{MOPIP})\right]^{2+}$ has been synthesized. The structure and composition was supported by analysis via ${ }^{\mathrm{I}} \mathrm{H}-\mathrm{NMR}$, mass spectrometry, elemental analysis, FT-IR, and UV-Vis spectroscopy. The binding properties of CT-DNA with the complex were studied by UV-Vis titration and viscosity measurements showed that the interaction occurred via intercalation mode giving the intrinsic binding constant of $\mathrm{K}_{\mathrm{b}}=1.67 \times 10^{6}$ $\mathrm{M}^{-1}$. $\left[\mathrm{Ru}(\mathrm{dppz})_{2}(p-\mathrm{MOPIP})\right]^{2+}$ was bound more tightly than similar related complexes. From the comparison, it was clear that the extended aromaticity of the ancillary ligand influenced the binding strength of ruthenium(II) complex to DNA. In the luminescence titration, it was found that the $\left[\mathrm{Ru}(\mathrm{dppz})_{2}(p-\mathrm{MOPIP})\right]^{2+}$ was a highly sensitive spectroscopic reporter of double-helical DNA. Whereas in aqueous solution, the luminescence was detectable only when $\left[\mathrm{Ru}(\mathrm{dppz})_{2}(p-\mathrm{MOPIP})\right]^{2+}$ intercalated in the nucleic acid structure and was perhaps shielded by DNA. Therefore, $\left[\mathrm{Ru}(\mathrm{dppz})_{2}(p \text {-MOPIP })\right]^{2+}$ was concluded that served as a true 'molecular light switch' for the DNA structures. The stark contrast between the 'off' and 'on' states of $\left[\mathrm{Ru}(\mathrm{dppz})_{2}(p-\mathrm{MOPIP})\right]^{2+}$ made this complex useful for the quantitative study of DNA and other non-polar microenvironments, a significant outcome for the design of novel intercalator reagents. However, the details of binding of complex with the sequence of DNA is not clear yet and further studies are required.

\section{Acknowledgement}

The authors gratefully acknowledge the Government of Malaysia for financial aid through Fundamental Research Grant Scheme (FRGS) project 01-01-14-1466FR. The authors would like to extend our thanks to those directly and indirectly involved in this project.

\section{References}

1. Balzani,V., Juris, A., Venturi, M., Campagna, S. and Serroni, S. (1996). Luminescent and redox-active polynuclear transition metal complexes. Chemical Reviews, 96 (2): 759 - 834.

2. Clarke, M. J. (2003). Ruthenium metallopharmaceuticals. Coordination Chemistry Reviews, 236 (1-2): 209 233.

3. Brabec, V. and Nováková, O. (2006). DNA binding mode of ruthenium complexes and relationship to tumor cell toxicity. Drug Resistance Update., 9 (3): $111-22$.

4. Allardyce, C. S. and Dyson, P. J. (2001). Ruthenium in medicine : Current clinical uses and future prospects. Platinum Metal Reviews, 45 (2): 62 - 69.

5. Allardyce, C. S., Dorcier, A., Scolaro, C. and Dyson, P. J. (2005). Development of organometallic (organotransition metal) pharmaceuticals. Applied Organometallic Chemistry, 19(1): 1-10.

6. Stephenson, T. and Wilkinson, G. (1966). Carboxylatoruthenium chlorides. Journal of Inorganic Nuclear Chemistry, 28: 2285 - 2291.

7. Maheswari, P. U., Rajendiran, V., Palaniandavar, M., Parthasarathi, R. and Subramanian, V. (2006). Synthesis, characterization and DNA binding properties of rac- $\left[\mathrm{Ru}(5,6-\mathrm{dmp})_{2}(\mathrm{dppz})\right]^{2+}$ - enantiopreferential DNA binding and co-ligand promoted exciton coupling. Journal of Inorganic Biochemistry, 100(1): $3-17$

8. Zhong, V., Huang, H., He, A. and Zhang, H. (2008). Synthesis and luminescent properties of novel polymeric metal complexes with bis(1,10-phenanthroline) group. Dye Pigment, 77 (3): 578 - 583.

9. Hiort, C., Lincoln, P. and Norden, B. (1993). DNA binding of DELTA- and LAMBDA-[Ru(phen) $\left.{ }_{2} \mathrm{dppz}\right]^{2+}$. Journal of The American Chemical Society, 115 (9): 3448 - 3454.

10. Liu, J., Zheng W., Shi, S., Tan, C., Chen, J., Zheng, K. and Ji, L. (2008). Synthesis, antitumor activity and structure-activity relationships of a series of Ru(II) complexes. Journal of Inorganic Biochemistry, 102 (2): 193 $-202$.

11. Sullivan, B. P., Meyer, T. J. and Salmon, D. J. (1978). Mixed phosphine 2,2'-bipyridine complexes of ruthenium. Inorganic Chemistry, 17 (12): 3334 - 3341.

12. Devi, C. S., Kumar, D. A., Singh, S. S., Gabra, N., Deepika, N., Kumar, Y. P. and Satyanarayana, S. (2013). Synthesis, interaction with DNA, cytotoxicity, cell cycle arrest and apoptotic inducing properties of ruthenium(II) molecular 'light switch' complexes. European Journal of Medicinal Chemistry 64: 410 - 421.

13. Huang, H-L., Liu, Y-J., Zeng, C-H., Yao, J-H., Liang, Z-H., Li, Z-Z. and Wu, F-H. (2010). Studies of ruthenium(II) polypyridyl complexes on cytotoxicity in vitro, apoptosis, DNA-binding and antioxidant activity. Journal of Molecular Structure, 966(1-3): 136- 143. 
14. Lan Jin, P. Y. (1997). Synthesis and DNA binding studies of Co(III) mixed-ligand complex containing dipyrido. Polyhedron, 16 (19): 3395 - 3398.

15. Lakowicz, J. (2007). Quenching of fluorescence. Principles of fluorescence spectroscopy, 277 - 330.

16. Zeglis, B. M., Pierre, V. C. and Barton, J. K. (2007) Metallo-intercalators and metallo-insertors. Chemical Communicatios (Cambridge),7345 (44): 4565 - 4579.

17. Friedman, A. E., Kumar, C. V., Turro, N. J. and Barton, J. K. (1991). Luminescence of ruthenium(II) polypyridyls: Evidence for intercalative binding to Z-DNA. Nucleic Acids Research, 19 (10): 2595 -2602.

18. Yu, Q., Liu, Y., Wang, C., Sun, D., Yang, X., Liu, Y. and Liu, J. (2012). Chiral ruthenium(II) polypyridyl complexes: Stabilization of G-Quadruplex DNA, inhibition of telomerase activity and cellular uptake. PLoS One, 7 (12): $1-13$.

19. Ahmad, H. (2009). Kinetically locked metallomacrocycles as self-assembled hosts for biomolecules. Ph.D Thesis.

20. Shi, S., Yao, T., Geng, X., Jiang, L. and Liu, J. (2009). Synthesis, characterization, and DNA binding of chiral complexes D - and L - $\left[\mathrm{Ru}(\text { bpy })_{2} \text { (pyip) }\right]^{2+}$. Chirality, 283: $276-283$.

21. Liu, J., Mei, W. J., Lin, L. J., Zheng, K. C., Chao, H., Yun, F. C. and Ji, L. N. (2004). Electronic effects on the interactions of complexes $\left[\mathrm{Ru}(\mathrm{phen})_{2}(\mathrm{p}-\mathrm{L})\right]^{2+}(\mathrm{L}=\mathrm{MOPIP}, \mathrm{HPIP}$, and NPIP) with DNA. Inorganica Chimica Acta, 357(1): 285 - 293.

22. Srishailam, A., Kumar, Y. P., Venkat Reddy, P., Nambigari, N., Vuruputuri, U., Singh, S. S. and Satyanarayana, S. (2014). Cellular uptake, cytotoxicity, apoptosis, DNA binding, photocleavage and molecular docking studies of ruthenium(II) polypyridyl complexes. Journal of Photochemistry and Photobiology B: Biology, 132: $111-123$.

23. Sun, J., An, Y., Zhang, L., Chen, H., Han, Y., Wang, Y., Mao, Z. and Ji, L. (2011). Studies on synthesis, characterization, and G-quadruplex binding of $\mathrm{Ru}(\mathrm{II})$ complexes containing two dppz ligands. Journal of Inorganic Biochemistry, 105 (2): 149 - 154.

24. Xu, L., Zhong, N.-J., Xie, Y.-Y., Huang, H.-L., Jiang, G.-B. and Liu, Y.-J. (2014). Synthesis, characterization, in vitro cytotoxicity, and apoptosis-inducing properties of ruthenium(II) complexes. PLoS One, 9 (5): e96082.

25. Rehman, S. U., Yaseen, Z., Husain, M. A., Sarwar, T., Ishqi, H. M. and Tabish, M. (2014). Interaction of 6 mercaptopurine with calf thymus DNA - Deciphering the binding mode and photoinduced DNA damage. PLoS One, 9(4): 1-11.

26. Shi, S., Liu, J., Li, J., Zheng, K-C., Huang, X-M., Tan, C-P., Chen, L-M. and Ji, L-N. (2006). Synthesis, characterization and DNA binding of novel chiral complexes delta- and lambda- $\left[\mathrm{Ru}(\mathrm{bpy})_{2} \mathrm{~L}\right]^{2+}(\mathrm{L}=\mathrm{o}$-mopip and p-mopip). Journal of Inorganic Biochemistry, 100(3): 385 - 395. 